Artigo / Article

\title{
Maturation of dendritic cells following exposure to different maturational stimuli
}

\section{Maturação das células dendríticas após exposição a diversos estímulos}

\author{
Aparecida M. Fontes ${ }^{1}$ \\ Maristela D. Orellana ${ }^{2}$ \\ Patricia V.B. Palma \\ Dimas T. Covas ${ }^{4}$
}

\begin{abstract}
Dendritic cells (DCs) are professional antigen-presenting cells that are highly effective to immunize against pathogens and tumor antigens. In order to obtain mature DCs several in vitro methods have been reported. Selecting the most efficient and effective method of generating morphologic and phenotypic DCs within 7 days of culture is an essential prerequisite for success in immunotherapy strategies. Herein, we report a method of obtaining an enriched monocyte population from blood donors and performed a comparison of DC maturation in response to four agents. Monocyte populations with $91 \% \pm 5$ of purity were obtained from 15 healthy donors. The resulting monocyte populations were cultured in the presence of GM-CSF and IL-4 during 5 days. At day 5 different maturation conditions were performed and morphological and phenotypical changes were analyzed. Our study demonstrates that TNF- $\alpha$ or $P G E_{1}$ by themselves can induce the expression of CD1a 2.4 and 2.7 times respectively more than DC cultures in the absence of maturing agents. On the other hand, for other costimulatory or accessory molecules (CD80, CD86, CD83 and CD40) TNF- $\alpha$ was more potent in the induction of expression than $P G E_{1}$, although in the presence of TNF- $\alpha$ plus PGE this effect is more pronounced compared to TNF- $\alpha$ alone. Under TNF- $\alpha$ plus $P G E_{1}$ treatment the phenotypical maturation of immature DCs are comparable to LPS and therefore TNF- $\alpha+P G E_{1}$ might be useful for generating exvivo DCs to use in protocols of cell vaccination. Further functional evaluation of these mature DCs is warranted. Rev. bras. hematol. hemoter. 2006;28(2):89-96.
\end{abstract}

Key words: Dendritic cells; monocytes; Percoll; maturation; immunotherapy.

\section{Introduction}

Dendritic cells (DCs), which were discovered more than 25 years ago, are the most potent members in the class of antigen-presenting cells (APCs) and are initiators and modulators of the immune response. They are mobile sentinels that bring antigens to T-cells and express costimulators for the induction of immunity. ${ }^{1,2}$ The exceptional ability of DCs to stimulate T-cells in vivo is attributed to their dichotomous nature, as immature and mature DCs. Immature DCs (iDCs), exist in peripheral tissues, where they continuously capture and process antigens, but they are relatively poor stimulators of T-cell responses. Upon exposure to inflammatory cytokines, iDCs upregulate costimulatory molecules and chemokine receptors. The first are required for the activation of antigen-specific T-cells, which takes place in the T-cell region of draining lymph nodes and the second are required for their migration to the lymph nodes. The mature dendritic cells (mDC) express a unique repertoire of cell-surface molecules including high levels of: a) molecules involved in antigen presentation to T-cells, such as, MHC class I, MHC class II and CD1a; b) adhesion molecules, such as, ICAM-1 (CD54), LFA-3 (CD58), Mac-1a (CD11c), SIRP-1a (CD172), VLA-4a

${ }^{1}$ PhD - Doutorado em Biologia Celular e Molecular FMRP/USP e Pós-doutorado no Dept ${ }^{\circ}$ Hematologia/Oncologia da CWRU/ Cleveland, OH, USA.

${ }^{2}$ Mestre em Imunologia Básica - IB/Unicamp - Campinas-SP.

${ }^{3}$ Bióloga PUC/Campinas-SP.

${ }^{4}$ PhD - Professor associado do Dept ${ }^{o}$ de Clínica Médica da Faculdade de Medicina de Ribeirão Preto - Universidade de São Paulo FMRP/USP.

Correspondence: Dimas T. Covas

Centro Regional de Hemoterapia de Ribeirão Preto - HC-FMRP/USP

14051-140 - Ribeirão Preto -SP - Brazil

Tel: 55-16-21019300 - Fax: 55-16-21019309

E-mail:dimas@fmrp.usp.br 
(CD49d) and VLA-5a (CD49e); c) costimulatory and accessory molecules, for example, B7-1 (CD80), B7-2 (CD86), CD40 and CD83 and d) chemokines receptors, such as, CCR7 and CXCR4. ${ }^{3,4}$

The key role of DCs in the initiation of immune responses has focused the attention of many investigators on the potential efficacy of these cells in tumor immunotherapy, ${ }^{5,6}$ for antiviral CTL responses ${ }^{7}$ and for antiinfection response for common intracellular pathogens such as leishmaniasis, histoplasmosis and mycobacterial species. ${ }^{8-10}$

The focus of our laboratory is to develop a very efficient and effective method of generating morphologic and phenotypic DCs within short periods to allow their use in cancer immunotherapy.

In developing strategies to optimize the use of dendritic cell-based immunotherapy in humans, several experimental methods have been reported. ${ }^{11-13}$ At present, most of the clinical trials use DCs generated from monocytes based on the findings of Sallusto and Lanzavechhia, ${ }^{14}$ which consist in the generation of mature DCs by culturing peripheral blood mononuclear cells in the presence of GM-CSF plus interleukin 4 (IL-4) for one week followed by stimulation with TNF- $\alpha$ for $48 \mathrm{~h}$. GM-CSF is a growth factor for stem cells from granulocyte and macrophage lineages ${ }^{15}$ and in DC cultures it appears to increase the expression of class II major histocompatibility complex (MHC) antigens, enhancing the antigen presenting capacity of DCs. IL-4 inhibits both granulocyte and macrophage development and it seems to keep DCs in an "immature" state, thus more capable of processing exogenous antigens. TNF- $\alpha$ in DC cultures appears to inhibit the granulocyte maturation and promotes the maturation of DCs to a state where they lose their ability to process antigens but are very active in stimulating naive lymphocytes.

As maturation is an essential part of DC function increasing effort has been devoted to study other maturation stimuli. Some other DC maturation stimuli include microbial products (e.g., lipopolysaccharide LPS, ${ }^{16-17}$ ), prostaglandin $\mathrm{E}\left(\mathrm{PGE},{ }^{18-19}\right)$, CD40 ligand ${ }^{20}$ and several combinations of these molecules have been used for ex vivo generation of mature DCs. ${ }^{13,21-23}$

It is well-established in these studies that exogenous prostaglandins $E_{2}$ or $E_{1}$ can enhance the TNF- $\alpha$-induced maturation in DCs as analysed by morphology, phenotype, ability to stimulate the allogeneic mixed leukocyte reaction, and induction of IL-12 production, ${ }^{13,19,24}$ but a systematic comparison of the phenotypical maturation of DCs generated from normal volunteers has not been performed yet.

In this study we performed a comparative study among four different DC maturation agents to investigate the influence of proinflammatory factors (TNF- $\alpha$ and PGE $_{1}$ ) in isolation or TNF- $\alpha$ in combination with PGE $_{1}$, as well as bacterial products (LPS) in the expression of each molecule characteristic of mature DCs, including CD1a, CD80, CD86, CD83 and CD40 evaluated by flow cytometry. Also, the characteristics of DCs were determined by evaluating their morphology by light microscopy. Our study demonstrates that TNF- $\alpha$ or PGE $_{1}$ by itself can increase the CD1a expression by 2.4 and 2.7 times, respectively, more than DC cultures in the absence of maturing agents. On the other hand, for other costimulatory or accessory molecules (CD80, CD86, CD83 and CD40) TNF- $\alpha$ was more potent to induce the expression compared to $\mathrm{PGE}_{1}$, although in the presence of TNF- $\alpha$ plus PGE $_{1}$ this effect is more pronounced compared

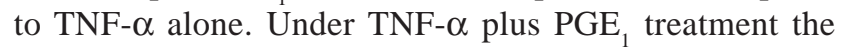
phenotypical maturation of immature DCs are comparable to LPS.

\section{Materials and Methods}

\section{Cell culture media and recombinant cytokines}

In all experiments, we used the complete RPMI-1640 (Sigma Chemical Company; St Louis, MO) medium supplemented with $10 \%$ heat-inactivated fetal bovine serum (Hyclone laboratories, Logan, UT), $2 \mathrm{mmol} / \mathrm{l} \mathrm{L-glutamine,}$ $100 \mathrm{U} / \mathrm{ml}$ penicillin, $100 \mu \mathrm{g} / \mathrm{ml}$ streptomycin (all from Gibco-BRL). Recombinant human granulocyte-macrophage colony-stimulating factor (GM-CSF), recombinant human interleukin-4 (IL-4), tumor necrosis factor- $\alpha$ (TNF- $\alpha$ ), prostaglandin- $\mathrm{E}_{1}$ and lipopolysaccharide (LPS) were all purchased from Sigma (Sigma Chemical Company; St Louis, $\mathrm{MO})$.

\section{Percoll gradient}

The $50 \%$ Percoll gradient (density $1.064 \mathrm{~g} / \mathrm{ml}$ ) as described by Almeida ${ }^{25}$ was used with one modification. First the isosmotic Percoll solution was prepared with one volume of PBS 10X (137 mM NaCl, $2.6 \mathrm{mM} \mathrm{KCl}, 8.45 \mathrm{mM}$ $\mathrm{Na}_{2} \mathrm{HPO}_{4}$ and $1.52 \mathrm{mM} \mathrm{KH}_{2} \mathrm{PO}_{4}$ ) and nine volumes of Percoll (Pharmacia, density $1.130 \mathrm{~g} / \mathrm{ml}$ ), afterwards the 50\% Percoll solution was prepared by mixing $1: 1(\mathrm{v} / \mathrm{v})$ isosmotic Percoll: PBS1X plus 0.6\% ACDA.

\section{Experimental design}

DCs were generated from leukocyte-enriched Buffy coats. The Buffy coat, derived from $500 \mathrm{ml}$ of whole blood drawn from a healthy volunteer, was supplied by the Blood Fractionation Laboratory of Regional Blood Center of Ribeirão Preto, in compliance with institutional guidelines and immediately processed. The leukocyte-enriched Buffy coats were diluted twice in PBS and the purification of highenriched monocyte population was obtained as follows: first the mononuclear cells were purified by Ficoll-Hypaque gradient (Pharmacia, density $1.077 \mathrm{~g} / \mathrm{ml}$ ) and centrifuged at $700 \mathrm{~g}$ for $30 \mathrm{~min}$ at room temperature. Afterwards, the MNCs were washed twice with PBS (final volume $20 \mathrm{ml}$ ) 
and centrifuged into $20 \mathrm{ml}$ of $50 \%$ Percoll solution at $400 \mathrm{~g}$ for $35 \mathrm{~min}$ at room temperature. The cells from the interface were collected, washed twice with PBS and the number of cells counted. The purity of monocyte population was evaluated by flow cytometry using an anti-CD14 antibody. The monocyte $\left(1 \times 10^{6} / \mathrm{ml}\right)$ was subsequently cultured in 24-well plates (Greiner Bio-One Gmblt, Frickenhausen) in complete RPMI-1640 medium. The following cytokines were used: $100 \mathrm{ng} / \mathrm{ml}$ human granulocyte-macrophage colonystimulating factor (GM-CSF) and $50 \mathrm{ng} / \mathrm{ml}$ of recombinant human IL-4 (both from Sigma) for 5 days. One-half of the culture volume was replaced with fresh medium and cytokines every 2 days. On day 5 , fresh whole medium was added and four different maturation conditions were tested: 1) TNF- $\alpha$ (10 ng/mL); 2) PGE $1\left(10^{-6} \mathrm{M}\right)$; 3) TNF- $\alpha$ (10 ng/ ml) plus PGE $_{1}\left(10^{-6} \mathrm{M}\right)$ and 4) LPS from E. coli (100 ng/ $\mathrm{ml})$. Simultaneously, as a control one-step culture, some samples were also maintained without adding additional factors. Following $48 \mathrm{~h}$ DCs were harvested and analyzed by light microscopy and by flow cytometry

\section{Immuno-phenotype analysis}

DCs and monocytes were analyzed for expression of cell surface markers by single-color cytometry. Cells were harvested after Percoll gradient separation and after culturing for seven days. A total of $1 \times 10^{6}$ cells was incubated for 30 minutes on ice in 2\% BSA containing phosphatebuffered saline (PBS) with the fluorescein isothiocyanate (FITC) - or phycoerythrin (PE) - conjugated mAb, or with control irrelevant isotype-matched mAb. The monoclonal antibodies used were: CD1a, CD80, CD86, CD83, CD40, CD14 and HLA-DR. HLA class II were analyzed by fluorescent-labeled Abs against HLA-DR. The stained cells were washed twice with PBS and fixed with $500 \mu \mathrm{L}$ of $2 \%$ paraformaldehyde in PBS. Then, cells were kept on ice, protected from light until flow cytometry analysis. Data acquisition of 10,000 events was performed using a FACSort ${ }^{\mathrm{TM}}$ flow cytometer (Becton Dickinson, San Jose, CA) and analysis was performed using Cell-Quest (Becton Dickinson) software. Dendritic cell regions were electronically gated according to light and forward scatter properties to exclude cell debris, dead cells and contaminating lymphocytes and granulocytes.

\section{Morphologic analysis}

Morphologic analysis was performed on an Axioskop 2 plus, Zeiss microscope (Carl Zeiss from Brazil). A total of $2 \times 10^{4}$ cells MNCs cultured for 2 days and DCs cultured for 7 days were cytocentrifuged using a Cytospin-3 centrifuge (Shandon Southern Products, Astmoor, UK) on microscope slides. Then, cytospins were air dried and stained with MayGrunwald-Giemsa before examining by light microscopy. Digital pictures were taken with a Zeiss Axioskop 2 plus (Carl Zeiss) microscope using a x100 NA 1.25 PlanApochromat oil lens and a AxionCam camera (Carl Zeiss). Digital images were subsequently converted into JPG format and imported into Adobe Photoshop 4.0 for editing and printing.

\section{Statistical analysis}

Descriptive statistics (arithmetic mean, median, and standard deviation) was used to describe each group of data.

\section{Results}

Enrichment of monocyte cells after Percoll gradient and morphological and phenotypical changes after culturing with GM-CSF plus IL-4

We obtained an enriched-CD14 $4^{+}$cell population after Percoll gradient centrifugation (Figure 1B). Starting with approximately 2-8 x $10^{8}$ peripheral blood mononuclear cells,
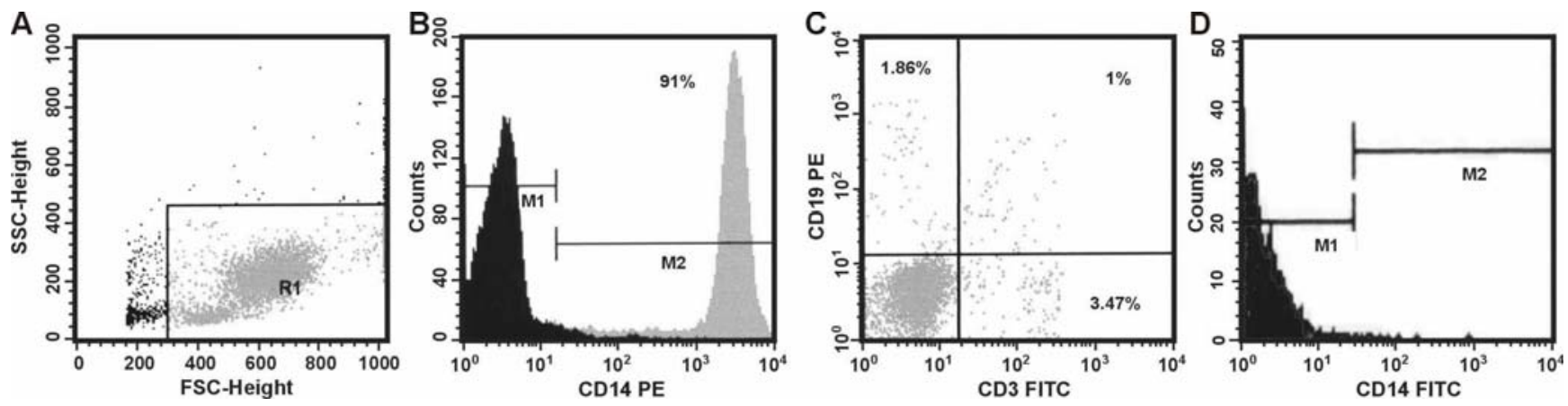

Figure 1. Enrichment of monocyte cells after Percoll gradient and downregulation of CD14 expression on immature DCs. Representative flow cytometric analysis, displaying the phenotype of monocytes cells after Percoll gradient and the absence of CD14 positive cells after seven days in the presence of GM-CSF and IL-4. (A) FSC vs. SSC profile. The R1 gate corresponds to monocyte population; (B) The collected monocyte cells are on average $94 \%$ CD14 positive (day 0). The black histogram is labeled with control irrelevant mAb and grey histogram is stained with PE-labeled CD14 $\mathrm{mAb}$; (C) The monocyte collected cells were analyzed by two-color cytometry for the expression of CD19 (B lymphocyte) and CD3 (T lymphocyte). The percentage of cells in each quadrant is listed, and (D) CD14 expression after 7 days in the presence of GM-CSF and IL-3. The immature DCs are CD14 negative. These data are from one representative experiment of a total of six performed 
we typically ended up with 5-8 $\times 10^{7}$ monocytes. Analysis by flow cytometry showed that the frequency of $\mathrm{CD} 14^{+}$ cells was $91 \% \pm 5$ and the lymphocyte contamination with $\mathrm{CD}^{+} / \mathrm{CD} 19^{+}$cells was low (Figure 1C). Moreover, as expected, there is a strong decrease in the expression of CD14 after 7 days in the presence of GM-CSF plus IL-4 (Figure 1D) or other culture conditions (data not shown).

Morphologically, the CD14 $4^{+}$cells appear with the typical monocyte morphology, which includes small cells with a plasma cell-like morphology and characterized by an eccentric nucleus and without dendritic projection (Figure 2A). After 7 days in the presence of GM-CSF plus IL-4 the cells became larger and few cytoplasmic projections were observed which is characteristic of immature DCs (Figure 2B). These results corroborated with the analysis by FACS where it was observed that, compared with the starting cell population, cells that were cultured with GM-CSF and IL-4 for 7 days increased in size and granularity (data not shown).

The expression of antigens including HLA DR and CD86 are upregulated in the starting cell population (median value of $81 \%$ and $97 \%$, respectively) while CD1a, CD40, CD80 and CD83 antigens are not detected (median value between 0.7 and 1.5\%). In the presence of GM-CSF plus IL-4 for 7 days is observed the differentiation of $\mathrm{CD} 14^{+}$cells into immature DCs as evaluated by FACS with a significantly higher expression of CD1a and CD80 (median of 34\% and 9\%, respectively).

The expression of HLA DR is retained in cells without any maturating agent while CD86 expression is decreased. Other phenotypes, including CD40 and CD83 showed a slightly higher expression compared with the starting cell population (Figure 3).

Effect of the addition of PGE 1 or TNF- $\alpha$ alone on phenotypical maturation of immature DCs

In the next series of experiments, we investigated the effect of $\mathrm{PGE}_{1}$ and TNF- $\alpha$ alone on the phenotypic maturation of human MoDCs. At day 5 immature MoDCs were treated with PGE $_{1}$ or TNF- $\alpha$ stimuli for 48 hours, and
Day 0

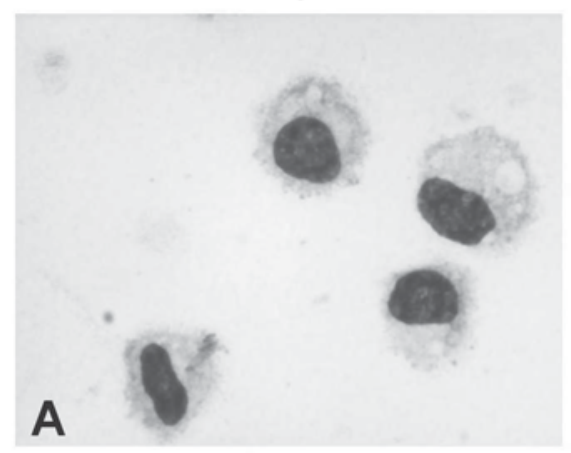

TNF $-\alpha$

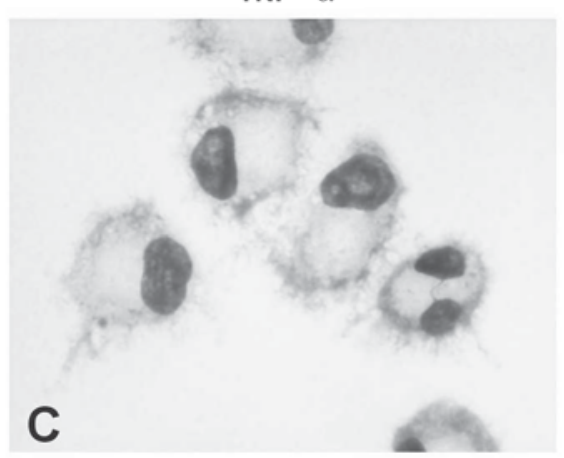

$\mathrm{TNF}-\mathrm{a}+\mathrm{PGE}_{1}$

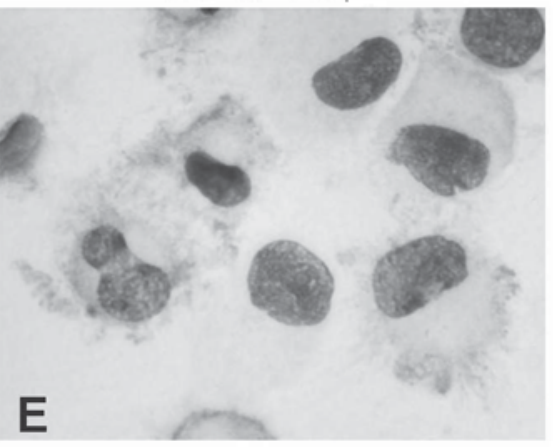

Figure 2. Morphological changes after culturing monocyte cells with GM-CSF plus IL-4 and in the presence or absence of different maturation stimuli. (A) Representative photographs of Wrightstained cytospins of enriched-CD14 ${ }^{+}$cells and immature and mature DC cultured for 7 days under different maturation stimuli: (A) enriched-CD14 ${ }^{+}$cell population; (B) immature-DCs; (C) TNF- $\alpha$-DCs; (D) PGE 1 -DCs; (E) TNF- $\alpha+$ PGE $_{1}$-DCs and (F) LPS-DCs. Magnification 100X.

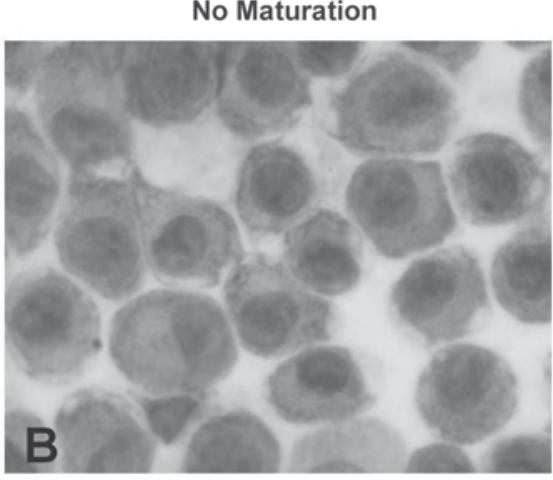

PGE-1
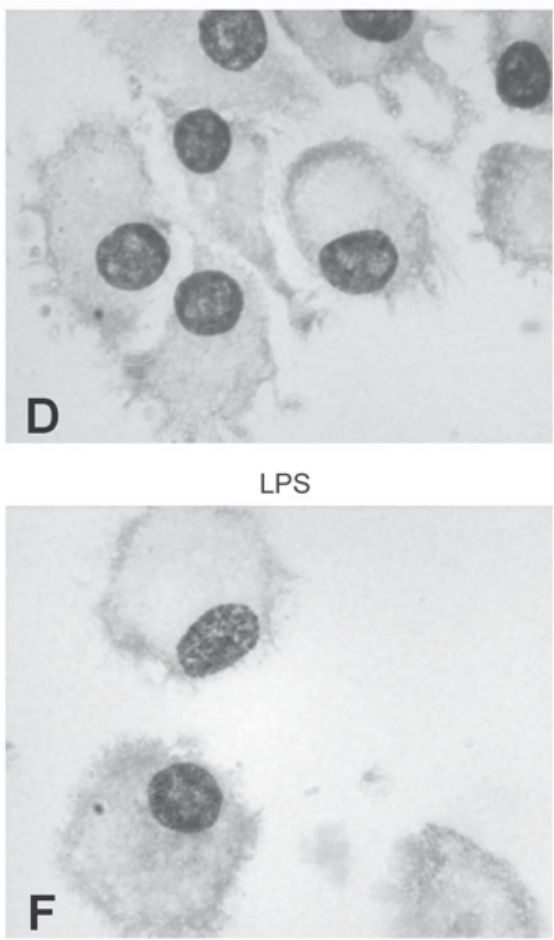

$\mathrm{F}$

the expression of maturity-related surface markers was analyzed by flow cytometry. As shown by flow cytometric analysis, in the presence of TNF- $\alpha$, or PGE 1 alone the expression of $\mathrm{CD} \mathrm{a}^{+}$is increased (median value of $82 \%$ and $94 \%$, respectively, versus $34 \%$ ). Related to the expression of the costimulatory CD80 molecule TNF- $\alpha$-DCs had a higher level of expression (median of $40 \%$ ) when compared to the levels of CD80 in immature DCs. On the contrary, CD80 expression could not be efficiently induced by DC exposed for $48 \mathrm{~h}$ to $\mathrm{PGE}_{1}$ alone (median of 26\%) when we compared with immature DCs (Figure 3).

Morphologically, under TNF- $\alpha$ (Figure 2C) or PGE ${ }_{1}$ 


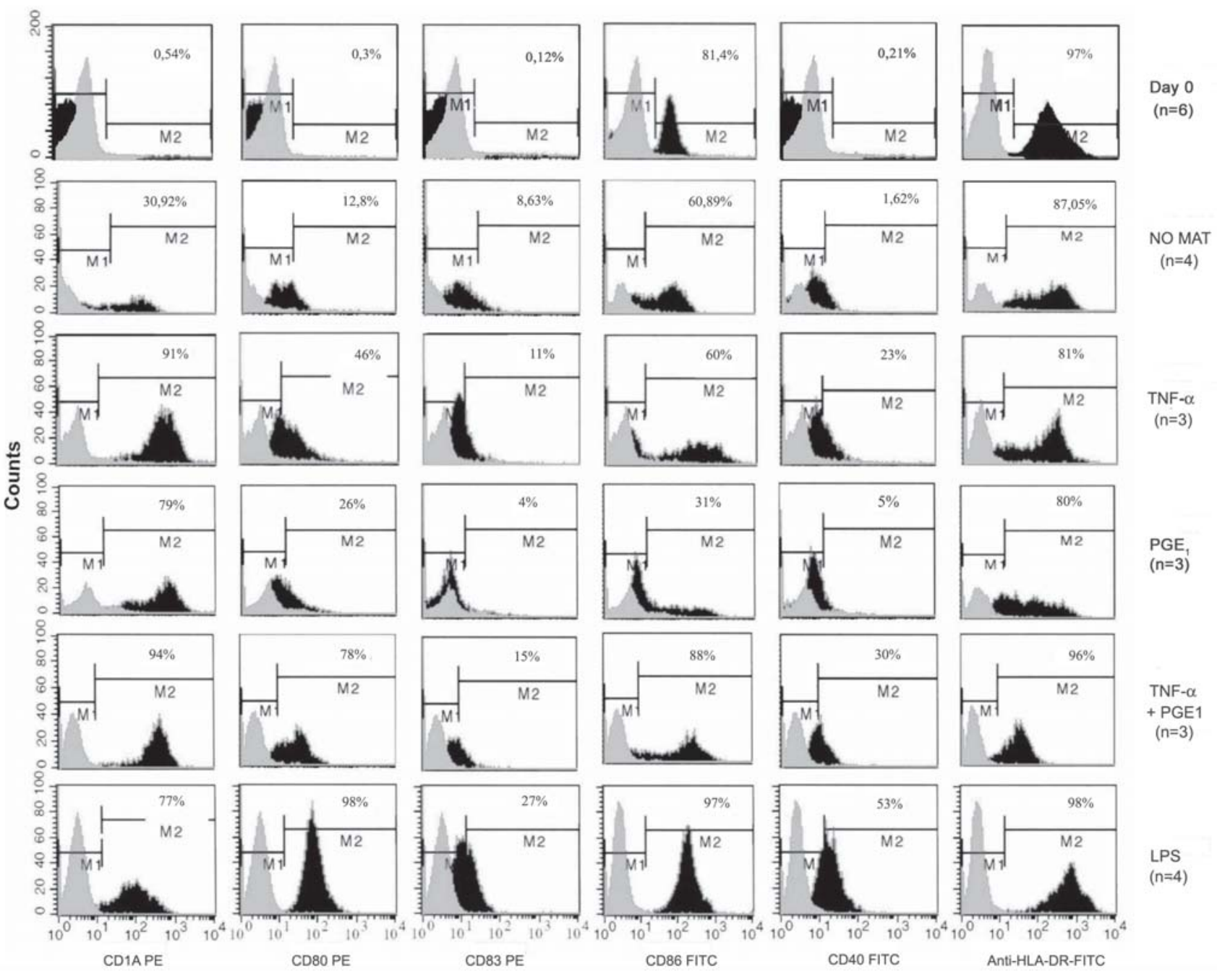

Figure 3. Greater expression of CD1a and CD80 costimulatory molecule in TNF- $\alpha+P_{\text {GE }}-\mathrm{DC}$ and LPS-DC than in TNF- $\alpha-D C$ and PGE ${ }_{1}-\mathrm{DC}$ cultures. CD14+ monocyte-derived DCs were cultured with GM-CSF + IL-4. At day 5 fresh medium was added for 2 days under different stimuli. Cells were harvested and analyzed at day 7 by FACS after labeling with the isotype controls and indicated mABs. Histograms show profiles of isotype controls (in grey) and monoclonal Abs (in black). Gates were set to include cells with large FSC and high SSC for DCs in the absence or presence of different maturating agents. Ten thousand gated events were collected for each analysis. Numbers indicate the percentage of CD expression. Data shown are representative of 3 to 6 experiments performed. The number of each DC culture conditions performed is indicated above each treatment

(Figure 2D), the cells exhibited an irregular shape and multiple cytoplasmic processes in many directions that typify dendritic cells. These results corroborated with the analysis by FACS where it was observed that the forward - and side - scatter distribution where higher than those of immature DCs, suggesting an increase in their size and granularity properties (data not shown).

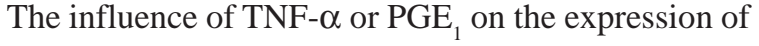
other antigens was also observed. As shown in Figure 3 under TNF- $\alpha$ treatment the expressions of HLA DR and CD86 remained similar to untreated DCs (median of $79 \%$ versus $82 \%$, and $69 \%$ versus $61 \%$, respectively), while the expressions of CD40 and CD83 were higher (median of 27\% versus $12 \%$, and $22 \%$ versus $4 \%$, respectively). Similarly, phenotypic analysis of DCs under PGE $_{1}$ treatment showed that the expression of HLA DR remained similar to untreated DCs (median of $78 \%$ versus $82 \%$ ), and the expression of CD40 was slightly higher (median of $18 \%$ versus $12 \%$ ). However, the expression of CD86 was downregulated (median of 31\% versus 61\%) and the expression of CD83 could not be stimulated (median of $4 \%$ ) in both DC cultures, in the presence or absence of PGE . $_{1}$

Taken together, these data indicated that TNF- $\alpha$ or $\mathrm{PGE}_{1}$ can increase the expression of CD1a 2.4 and 2.7 times, respectively, more than DC cultures in the absence of the maturing agent. However, for other costimulatory or accessory molecules (CD80, CD86, CD83 and CD40) TNF- $\alpha$ was more potent in the induction of the expression than $\mathrm{PGE}_{1}$, suggesting that additional maturation factors are essential for obtaining efficiently matured DCs. 
The presence of $P G E_{1}$ plus TNF- $\alpha$ has similar effect on phenotypical maturation of immature DCs compared to LPS

In the third series of experiments, we investigated the

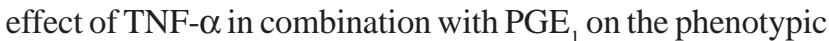
maturation of human $\mathrm{CD} 14^{+}$derived-DCs (Mo-DCs). At day 5 , immature Mo-DCs were treated with TNF- $\alpha$ plus PGE stimuli for 48 hours, and the expression of maturity-related surface markers was analyzed by flow cytometry. Consistent with a previous work, DCs exposed to TNF- $\alpha$ plus PGE have a higher expression of costimulatory and accessory molecules, CD80 and CD86 than DCs stimulated with TNF$\alpha$ or PGE alone. $^{13}$ Moreover, CD1a showed an elevated expression. As shown by flow cytometry analysis in the

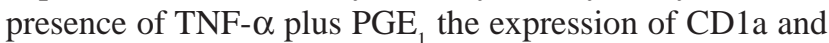
CD80 were elevated appreciably when compared with untreated-DCs (median of $90 \%$ and $79 \%$, respectively, versus $34 \%$ and 9\%). Also, as expected HLA DR and CD86 expression remained high and similar to untreated-DCs (median of $70 \%$ and $81 \%$, respectively, versus $82 \%$ and 61\%). Therefore, on the contrary to $\mathrm{PGE}_{1}$ treatment where a decrease of CD86 expression (median of 14\%) was observed the combination TNF- $\alpha$ and PGE $_{1}$ cooperate to activate the expression of CD86 (median of 70\%). Surprisingly, TNF- $\alpha$ plus PGE $_{1}$ treated-DCs did not show significant increases of CD40 and CD83 expression compared to untreated or TNF- $\alpha$-DCs and PGE-DCs (median of $28 \%$ and $19 \%$, respectively, versus $12 \%$ and $4 \%$ for untreated-DCs; versus $27 \%$ and $22 \%$ for TNF- $\alpha$-DCs and versus $12 \%$ and $4 \%$ for PGE - -DCs). These results can be explained by DC-culture conditions (see comments on discussion) or by induction of a specific subset of dendritic cells.

Morphologically, under TNF- $\alpha$ plus PGE $_{1}$ treatment (Figure 2D) the cells exhibited a shape similar to TNF- $\alpha$ treated-DCs or PGE ${ }_{1}$ treated-DCs with an irregular shape and multiple cytoplasmic processes in many directions that typify dendritic cells.

We next explored the relevance for the observed enhancement of DC maturation in the presence of TNF- $\alpha$ plus $\mathrm{PGE}_{1}$. At day 5 , immature CD14+-derived DCs were treated with LPS stimuli for 48 hours, and the expression of maturation-related surface markers was analyzed by flow cytometry. In LPS-DCs there were no significant differences in the levels of the expressions of CD1a, CD80, CD86 and CD83 compared to TNF- $\alpha$ plus PGE - -DCs (median of $81 \%$, $97 \%, 98 \%$ and $21 \%$ versus $90 \%, 79 \%, 81 \%$ and $19 \%$, respectively, $\mathrm{p}>0.05)$. Sequential analysis of other antigens showed that, the expression of HLA DR and CD40 has a more pronounced effect in the presence of LPS compared to TNF- $\alpha$ plus PGE $_{1}$ treatment (median of $97 \%$ and $67 \%$ versus $70 \%$ and $28 \%$, respectively).

Thus, CD14 ${ }^{+}$-derived DCs treated with TNF- $\alpha+\mathrm{PGE}_{1}$ display phenotypic mature characteristics for CD1a, CD80 and CD86 molecules similar to LPS-treated DCs and higher than their TNF- $\alpha$ treated-DC or PGE $_{1}$ treated-DC or untreated-DC counterparts.

\section{Discussion}

A variety of strategies to generate DCs are currently under investigation and there has been an increasing need to define the most promising candidate therapies for clinical studies. At present, most of the preclinical studies use DCs generated from monocytes isolated after adherence in culture flasks or from monocytes isolated after depleting lymphocyte cells with an immune magnetic column. Thus, the enrichedCD14 ${ }^{+}$monocyte cell population is differentiated into DCs in a two-step culture. In the first step GM-CSF and IL-4 promote the differentiation of immature monocyte derived DCs (iDCs) and in the second step pro-inflammatory factors induce the terminal maturation of DCs. ${ }^{12-13,21,24,26-28}$

The studies described here have two proposes, first to establish a low cost and highly efficient technique to obtain an enriched-CD14 $4^{+}$monocyte cell population and second to perform a systematic comparison of the phenotypical maturation of DCs generated from different maturing agents that have been used in clinical assays.

The adherence of PBMCs in culture plates for two hours at $37^{\circ} \mathrm{C}$ could be considered the "gold standard" to isolate monocyte cell populations from progenitor PBMCs. However, the contamination with lymphocytes may be high. On the other hand, the second approach, which consists of using a immune magnetic column, is too expensive for daily routine. In this study we obtained a CD14 ${ }^{+}$enriched cell population by performing Percoll gradient from PBMCs. The results of FACS analysis of the recovered cells indicate that $91 \% \pm 5 \%$ were CD14 ${ }^{+}$cells and the content of cells expressing $\mathrm{T}$ and $\mathrm{B}$ markers were low. Additionally, these cells strongly express HLA DR and CD86 and lack expression of CD1a, CD40, CD80 and CD83.

We further observed that when these cells are stimulated in vitro with GM-CSF and IL-4 the cells can survive and enter cell cycles for in vitro DC development generating a typical iDC phenotype as they acquired CD1a and CD80 (median of 34\% and 9\%, respectively) while loosing CD14 expression. Moreover, the expression of HLA DR is retained, while CD86 expression decreases.

The question about which is the most efficient cocktail of cytokines to produce mature DCs has been addressed previously by several laboratories. In these studies, the presence of exogenous prostaglandins $E_{2}$ or $E_{1}$ enhanced the TNF- $\alpha$ induced maturation of DCs as analyzed by morphology, phenotype, ability to stimulate the allogeneic mixed leukocyte reaction and induction of IL-12 production. ${ }^{13,23,29}$ Also, the bacterial lipopolysaccharide (LPS) is known to be an inflammatory stimulus and has been shown to activate DCs, as well as, whole pathogens or other 
components of microorganisms (e.g. dsRNA, CpG DNA and toxins, ${ }^{29-30}$ ).

However, our study is uniquely extensive in that we performed a systematic comparison with the yield of all spectra of DC markers that have been used to address the DC maturation before and after being exposed to four different maturating agents, including TNF- $\alpha, \mathrm{PGE}_{1}$, TNF- $\alpha$ plus PGE $_{1}$ and LPS.

Consistent with other studies, ${ }^{13,23,29}$ we show that TNF- $\alpha$ or $\mathrm{PGE}_{1}$ alone are capable of inducing the maturation of DCs. Our TNF- $\alpha$-treated DCs or PGE - -treated DCs displayed higher expressions of CD1 ${ }^{+}$compared with untreated DCs (median value of $82 \%$ and $94 \%$, respectively, versus 34\%) and some differences were found between both treatments. Analysis of the costimulatory and accessory molecules CD80, CD86, CD40 and CD83 showed a higher level after TNF- $\alpha$ treatment compared with PGE 1 treatment (median value of $40 \%, 78 \%, 27 \%$ and $22 \%$ versus and $26 \%$, $13 \%, 4 \%$ and $4 \%$, respectively). However, studies by Steinbrink et al. ${ }^{13}$ demonstrated that PGE $_{1}$-treated DCs are CD1a ${ }^{-}$and display higher expressions of CD80, CD86, CD40 and CD83 (81\%, 80\%, 50\% and 55\%, respectively). One possible explanation for this discrepancy is the differences in the culture conditions chosen. Steinbrink et al. ${ }^{13}$ favored X-VIVO $15+1 \%$ autologous plasma + GM-CSF + IL-4 for 7 days followed by the maturation with $\mathrm{PGE}_{1}$ for 2 days. As reported by Jonuleit et al., ${ }^{21}$ conceivably X-VIVO-cultured cells show a maturer activation/differentiation stage in comparison to RMPI-cultured cells, which may need additional signals, or a longer time in cultures. These authors also detected lower expressions of CD83 in PGE -treated $_{1}$ DCs or TNF- $\alpha$-treated DCs under RPMI conditions, while Lee et al. ${ }^{23}$ obtained matured DCs with a higher expression of this CD marker on day 9 in cultured cells with RPMI conditions after TNF- $\alpha$ treatment. On the other hand, our TNF- $\alpha$-treated DCs are CD1a ${ }^{+}$, and in agreement with a previous work this proinflammatory cytokine up-regulates the MHC class I expression as well as immune proteasome and TAP molecules at the cell surface of several Melanoma cell lines ${ }^{31}$ suggesting that TNF- $\alpha$ treatment is critical for an efficient immune response.

Moreover, considering that our TNF- $\alpha$ plus PGE - $_{1}$ treated DCs show a three to five fold higher expression of CD80, CD40 and CD83 (median of 79\%, 28\% and 19\%, respectively) as well as $\mathrm{CD} 1 \mathrm{a}^{+}$remaining highly expressed (median of $90 \%$ ) together with the fact that these data are comparable to DCs generated using LPS in vitro we therefore suggest that the combination TNF- $\alpha+$ PGE $_{1}$ might be useful for generating ex-vivo DCs for efficient processing and presentation of antigens and therefore could be used as a cellular vaccines. LPS is known to be a potent stimulator of DC maturation ${ }^{32}$ however it has not been approved for clinical use because it can induce substantial toxicity. Further functional evaluation of these mature DCs is warranted.
Also, these three maturating agents, $\mathrm{PGE}_{1}, \mathrm{TNF}-\alpha$ and LPS, mediate their effects by distinct mechanisms: a) $\mathrm{PGE}_{2}$, a member of the same PGE 1 family, mediates its effect on monocytoid cells via $4 \mathrm{G}$ protein-coupled receptors (EP1, EP2, EP3 and EP4) two of which mediate their signal through elevated cyclic adenosine monophosphate (cAMP, 33-34); b) TNF- $\alpha$ mediates its effects via CD134 and CD137 receptors; the latter has been shown to be expressed on follicular dendritic cells ${ }^{35}$ and c) LPS mediates its effect on DC activation via TLR4 specific receptors on the surface of the DC. ${ }^{36}$ The exact downstream signaling responses are not clearly understood, but these distinct receptors suggest distinct targeted genes and may also explain the differences observed among DCs generated ex-vivo.

Further studies to elucidate the molecular mechanism involved in the maturation process of DCs is essential not only to understand the biology of DCs but also to optimize dendritic cell immunotherapy in humans.

\section{Resumo}

Células dendríticas (CDs) são células apresentadoras de antígenos altamente eficientes para a imunização contra patógenos e antígenos tumorais. A obtenção de CDs maturis tem sido descrita por diferentes métodos. Portanto, a escolha do método mais apropriado para gerar CDs em cultura de sete dias é pré-requisito essencial para as estratégias imunoterápicas. Aqui relatamos um método de obtenção de uma população enriquecida em monócitos de doadores de sangue e comparamos a maturação das CDs sob o estímulo de quatro agentes. Uma população de monócitos, com pureza de $91 \% \pm 5$, foi obtida de 15 doadores. A população monocitária foi mantida em cultura por cinco dias com GM- CSF e IL - 4. No $5^{\circ}$ dia, após diferentes condições de maturação, foram analisadas as modificações morfológicas e fenotípicas. Nossos estudos demonstram que o TNF- $\alpha$ ou o PGE 1 por si só podem induzir a expressão de CD1a de 2.4 a 2.7 vezes, respectivamente, mais do que culturas de CDs com ausência dos agentes de maturação. Alternativamente, para com outras moléculas coestimuladoras ou acessórias (CD80, CD86, CD83 e CD 40) o TNF- $\alpha$ foi mais potente na expressão do que o $P G E_{1}$, embora na presença de ambos o efeito seja mais pronunciado. A maturação fenotípica sob TNF- $\alpha+P G E_{1}$ pode ser comparável ao LPS, concluindo que o TNF- $\alpha+P G E_{1}$ pode ser útil para geração ex-vivo de CDs e útil para protocolos de vacinação celular. Avaliação funcional das CDs é recomendável. Rev. bras. hematol. hemoter. 2006;28(2):89-96.

Palavras-chave: Células dendríticas; monócitos; Percoll; maturação; imunoterapia.

\section{Acknowledgments}

We thank Dr. Rita Viu Carrara for help in morphological analysis of DCs, Fabiana Rossetto de Morais for help in FACS analysis and Sandra Navarro Bresciani for her expert assistance in figure design. 


\section{References}

1. Banchereau J, Steinman L. Dendritic cells and the control of immunity. Dendritic cells and the control of immunity. Nature 1998; 392:245-52.

2. Banchereau J, Briere F, Caux C, et al. Immunobiology of dendritic cells. Annu Rev Immunol 2000;18:767-811.

3. Sozzani, S, Allavena P, Vecchi A, et al. Chemokines and dendritic cell traffic. J Clin Immunol 2000;20:151-60.

4. Guermonprez P, Valladear J, Zitvogel L, et al. Amigorena S. Antigen presentation and T cell stimulation by dendritic cells. Ann Rev Immunol 2002;20:621-667.

5. Dhodapkar MV, Bhardwaj N. Active immunization of human with dendritic cells. J Clin Immunol 2000;20:167-74.

6. Gunzer M, Janich S, Varga G, et al. Dendritic cells and tumor immunology. Sem Immunol 2001;13:291-302.

7. Fonteneau JF, Larsson M, Bhardwaj N. Interactions between dead cells and dendritic cells in the induction of antiviral CTL response. Cur Opin Immunol 2002;14:471-7.

8. Quimones M, Ahuja SK, Melby PC, et al. Preformed membrane-associated stores of interleukin (IL)-12 are a previously unrecognized of bioactive IL-12 that is mobilized with minutes of contact with an intracellular parasite. J Exp Med 2000;192:507-16.

9. Richards JO, Ampel NM, Galgiani JN, et al. Dendritic cells pulsed with Coccidioides immitis lysate induce antigen-specific naive T cell activation. J Inf Diseases 2001;184:1.220-24.

10. Zheng M, Shellito JE, Marrero L, et al. CD4+ T cell-independent vaccination against Pneumocystis carinii in mice. J Clin Invest 2001; 108:1.469-74.

11. Zheng Z, Takahashi M, Narita M, et al. Generation of dendritic cells from adherent-cells of cord blood by culture with granulocytemacrophage colony-stimulating factor, interleukin-4, and tumor necrosis factor- $\alpha$. J Hemat Stem Res 2000;9:453-64.

12. Suen Y, Lee SM, Aono F, et al. Comparison of monocyte enrichment by immuno-magnetic depletion or adherence for the clinical-scale generation of DC. Cytotherapy 2001;3:365-72.

13. Steinbrink, K, Paragnik L, Jonulcit H, et al. Induction of dendritic cell maturation and modulation of dendritic cell-induced immune responses by prostaglandins. Arch Dermatol Res 2000;292:437-45.

14. Sallusto F, Lanzavecchia A. Efficient presentation of soluble antigen by cultured human dendritic cells is maintained by granulocyte/macrophage colony-stimulating factor plus interleukin 4 and downregulated by tumor necrosis factor alpha. J Exp Med 1994;179(4):1.109-18.

15. Metcalf D. Multi-CSF-dependent colony formation by cells of a murine haemopoietic cell line: specificity and action of multi-CSF. Blood 1985; 65(2):357-62.

16. Verhasselt V, Buelens C, Willems F, et al. Bacterial lipopolysaccharide stimulates the production of cytokines and the expression of costimulatory molecules by human peripheral blood dendritic cells: evidence for a soluble CD14-dependent pathway. J Immunol 1997;158:2.919-25.

17. Triantafilou M, Triantafilou K. Lipopolysaccharide recognition: CD14, TLRs and the LPS-activation cluster. Trends Immunol 2002;23(6): 301-4.

18. Phipps RP, Stein SH, Roper RL. A new view of prostaglandin E regulation of the immune response. Immunol Today 1991;12(10):349-52.

19. Zelle-Rieser C, Ramoner R, Artner-Dworzak E, et al. Human monocytederived dendritic cells are deficient in prostaglandin E2 production. FEBS Letters 2002;511:123-6.

20. Bennett S, Por SB, Stanley ER, Breit SN. Monocyte proliferation in a cytokine-free, serum system. J Immunol Methods 1992;153:201-12.

21. Jonuleit H, Kuhn U, Muller G, et al. Pro-inflammatory cytokines and prostaglandins induce maturation of potent immunostimulatory dendritic cells under fetal calf serum-free conditions. Eur J Immunol 1997;27 (12):3.135-42.
22. Kalinski P, Schuitemaker JH, Hilkens CM, et al. Prostaglandin E2 induces the final maturation of IL-12-deficient CD1a+CD83+ dendritic cells: the levels of IL-12 are determined during the final dendritic cell maturation and are resistant to further modulation. J Immunol 1998. 15:161(6):2.804-9.

23. Lee AW, Truong T, Bickham K et al. A clinical grade cocktail of cytokines and PGE(2) results in uniform maturation of human monocyte-derived dendritic cells: implications for immunotherapy Vaccine 2002;20 Suppl 4:A8-A22.

24. Scandella E, Men Y, Gillesen S, et al. Prostaglandin E2 is a key factor for CCR7 surface expression and migration of monocyte-derived dendritic cells. Blood 2002;100:1.354-61.

25. de Almeida MC, Silva AC, Barral A, et al. A simple method for human peripheral blood monocyte isolation. Mem Inst Oswaldo Cruz 2000; 95(2):221-3.

26. Palucka KA, Taquet N, Sanchez-Chapuis F, et al. Dendritic cells as the terminal stage of monocyte differentiation. J Immunol 1998;160 (9):4.587-95.

27. Cao H, Verge V, Baron C, et al. In vitro generation of dendritic cells from human blood monocytes in experimental conditions compatible for in vivo cell therapy. J Hematotherapy Stem Cell Res 2000;9(2):183-94.

28. Luft T, Jefford M, Luetjens $P$, et al. Functionally distinct dendritic cell (DC) populations induced by physiologic stimuli: prostaglandin E(2) regulates the migratory capacity of specific DC subsets. Blood 2002; 100(4):1.362-72.

29. Sallusto F, Cella M, Danieli C, et al. Dendritic cells use macropinocytosis and the mannose receptor to concentrate macromolecules in the major histocompatibility complex class II compartment: downregulation by cytokines and bacterial products. J Exp Med 1995;182(2):389-400.

30. Brightbill HD, Libraty DH, Krutzik SR, et al. Host defense mechanisms triggered by microbial lipoproteins through toll-like receptors. Science 1999;285(5428):732-6.

31. Hallermalm K, Seki K, Wei C, et al. Tumor necrosis factor-alpha induces coordinated changes in major histocompatibility class I presentation pathway, resulting in increased stability of class I complexes at the cell surface. Blood 2001;98(4):1.108-15.

32. Brunner C, Seiderer J, Schlamp A, et al. Enhanced dendritic cell maturation by TNF-alpha or cytidine-phosphate-guanosine DNA drives T cell activation in vitro and therapeutic anti-tumor immune responses in vivo. J Immunol 2000;165(11):6.278-86.

33. Breyer RM, Bagdassarian CK, Myers AS, et al. Prostanoid receptors: subtypes and signaling. Ann Rev Pharmacol Toxicol 2001;41:661-90.

34. Ikegami R, Sugimoto Y, Segi E, et al. The expression of prostaglandin E receptors EP2 and EP4 and their different regulation by lipopolysaccharide in C3H/HeN peritoneal macrophages. J Immunol 2001; 166(7):4.689-96.

35. Lindstedt M, Johansson-Lindbom B, Borrebaeck CA. Expression of CD137 (4-1BB) on human follicular dendritic cells. Scand J Immunol 2003; 57(4):305-10.

36. Schnare M, Barton GM, Holt AC, et al. Toll-like receptors control activation of adaptive immune responses. Nature Immunol 2001; 2(10):947-50.

Avaliação: Editor e dois revisores externos.

Conflito de interesse: não declarado

Recebido: 19/12/2005

Aceito após modificações: 09/02/2006

Recursos financeiros: Fundherp Foundation and grants from Fapesp (1998/14247-6) and CNPq (62.0019/99.9) 